\title{
Mining the human genome after Association for Molecular Pathology v. Myriad Genetics
}

\author{
Barbara J Evans, PhD, JD ${ }^{1}$
}

The Supreme Court's recent decision in Association for Molecular Pathology v. Myriad Genetics portrays the human genome as a product of nature. This frames medical genetics as an extractive industry that mines a natural resource to produce valuable goods and services. Natural resource law offers insights into problems medical geneticists can expect after this decision and suggests possible solutions. Increased competition among clinical laboratories offers various benefits but threatens to increase fragmentation of genetic data resources, potentially causing waste in the form of lost opportunities to discover the clinical significance of particular gene variants. The solution lies in addressing legal barriers to appropriate data sharing. Sustainable discovery in the field of medical genetics can best be achieved through voluntary data sharing rather than command-and-control tactics,

The Supreme Court's decision in Association for Molecular Pathology (AMP) v. Myriad Genetics invalidated patents on isolated gene sequences, but complementary DNA continues to be patentable subject matter. ${ }^{1}$ Existing patents on complementary DNA will remain in force, but complementary DNA may no longer be novel and nonobvious enough to keep getting new patents in the future. America's long dalliance with gene patents appears to be ending. The policy challenge today is the same that existed in the early 1990s when gene patents seemed a promising approach: genomic medicine is informational medicine, and for information to be useful, it needs to be shared. Medical genetics needs a legal framework that promotes appropriate information sharing while still allowing innovators who create the information to make a living doing so.

Gene patents did not strike this balance in an ideal way for medical genetics. Innovators must disclose their inventions in order to get a gene patent but, even under the stricter 2001 utility standards, ${ }^{2}$ the required disclosures left medical geneticists short of information. There is a need for verifiable information about the clinical validity and utility of specific gene variants, and verifiability implies access not just to scientific conclusions but to data sufficient to reproduce those conclusions. ${ }^{3}$ Such information often accrues only after a genetic test is commercialized and linked with clinical data for many patients-in other words, long after the patent office has issued a patent that may itself impede the process of information accrual and data sharing. but voluntary mechanisms must be conceived broadly to include market-based approaches as well as donative and publicly funded data commons. The recently revised Health Insurance Portability and Accountability Act Privacy Rule offers an improved-but still imperfect-framework for market-oriented data sharing. This article explores strategies for addressing the Privacy Rule's remaining defects. America is close to having a legal framework that can reward innovators, protect privacy, and promote needed data sharing to advance medical genetics.

Genet Med advance online publication 19 December 2013

Key Words: Association for Molecular Pathology v. Myriad Genetics; CLIA; data sharing; genetic databases; gene patents; HIPAA; innovation policy

The AMP v. Myriad decision seemingly helps promote future discovery by allowing wider use and study of particular genes. There is a potential downside, however: as more parties use and study specific gene variants, the data they generate become siloed in multiple, separate data sets. Legal barriers to data sharing (including privacy and human-subject protections) tend to perpetuate silos once they exist. Fragmentation of data resources may itself impede future discovery, absent workable legal pathways to share data to assemble comprehensive data sets. Natural resource law grapples with strikingly similar problems and offers a framework for resolving them.

\section{DISCUSSION}

$A M P$ v. Myriad treats genetic material as a product of nature: the genome is a natural resource that scientists discover but do not invent. The genome clearly fits the definition of a natural resource: "something ... that is found in nature and is necessary or useful to humans."4 By accepting this fact, the Supreme Court positioned medical genetics under the framework of natural resource law and, in effect, recast medical genetics as an extractive, rather than inventive, industry.

Extractive industries-such as mining, fishing, and energy wind farms-discover natural resources and develop infrastructures to extract them from their natural settings and convert them into products and services people can use. That is what medical geneticists do, using infrastructures that include 
laboratories, databases, biobanks, and health information systems. The infrastructures use innovative technologies that may be eligible for intellectual property protection, but the resources themselves are not. One cannot patent the wind, and one should not patent genes. Resource law grants rights-including exclusive rights-to people who discover or commercially develop natural resources, but it differs from patent law in important ways explored later in this article.

Treating the genome as a natural resource in no way implies that it is a bulk, undifferentiated commodity. Some resources (such as gravel) are fungible, but others (such as the rock containing the Hope diamond) have unique features. The gene deposits found in each individual have unique attributes meaningful to geneticists, just as gold mines have distinctive geologi$\mathrm{cal}$ and chemical characteristics significant to metallurgists.

Calling the genome a natural resource states no position on whether genetic data should be public or private property. Natural resources can be either. Some are public goods (the atmosphere); others can be privately owned (farmland). Natural resource entitlements have been debated through the millennia ${ }^{5}$ as intensely as genetic data ownership is debated today ${ }^{6}$ Under the old res nullius doctrine, nobody owned subsoil minerals until someone discovered or took possession of them. ${ }^{4}$ The State merely registered claims, much like a patent office issuing patents. Rarely used today, it let private owners stake claims as in the Klondike gold rush.

Some nations-notably, the United States-follow accession doctrine, which dates to early Roman law. ${ }^{4}$ It grants surface landowners a right to subsurface minerals and results in private ownership and trading of mineral rights. ${ }^{4}$ Letting patients own and trade the genetic information beneath their skins would resemble accession. Many nations instead embrace state ownership - rooted in postclassic Roman law circa 230-530 ADwhich vests mineral rights in the state as representative of the people. ${ }^{4}$ The United States uses accession doctrine for minerals under private land but public ownership of resources off shore and under public lands.

An advantage of resource law is that exclusive rights to extract natural resources typically carry reciprocal civic duties. For example, the US Bureau of Ocean Energy Management, acting for the American people, allocates exclusive rights to produce oil from 8,000 oil and gas leases covering 1.7 billion acres of the Outer Continental Shelf. ${ }^{7}$ Qualified producers bid for the privilege of commercially developing each lease, agreeing to share part of the wealth they extract with the government and to develop the lease diligently and subject to environmental and other requirements. Even when resources are privately owned, governments impose environmental, reclamation, and other civic duties by regulation.

Had genes originally been framed as natural resources rather than as patentable subject matter, Myriad's exclusive right to extract commercial value from the breast cancer 1 (BRCA1) and $B R C A 2$ genes might have carried with it, for example, duties to share data about the clinical validity and utility of the gene variants that Myriad detected. Instead, Myriad was able to treat data derived from $B R C A$ testing as one of the spoils of patent exclusivity, strangely resurrecting the ancient res nullius doctrine for genetic information. After November 2004, Myriad chose-as it had every legal right to do-to stop contributing data to public databases and now holds proprietary data on genetic variants of unknown significance that help decipher the clinical meaning of BRCA tests. ${ }^{8}$

Commenting on the world's mining and petroleum industries, the Extractive Industries Transparency Initiative notes that " 3.5 billion people live in resource-rich countries. Still, many are not seeing the benefits from extraction of their natural resources." Sadly, under the gene patenting regime of the past 2 decades, Americans did not see the full benefits from extraction of their genomic resources. Many insights extracted from their genes are locked away in proprietary databases.

\section{Defining the resource}

In medical genetics, the theoretically minable resource includes the genomes and the clinical information of all living human beings, plus those of any deceased individuals for whom such information has been preserved. In practice, the available resource base is considerably smaller because most people now alive will never undergo genetic testing.

The World Health Organization estimates that " 2.6 billion people-half the developing world-lack even a simple "improved" latrine and 1.1 billion people has no access to any type of improved drinking source of water." ${ }^{10}$ These unplumbed souls are unlikely to have their genomes sequenced and are not part of the resource base from which medical genetics can extract useful discoveries. Other unrecoverable genomes include those of insured people who lack a clinical indication that makes genetic testing medically necessary, the uninsured who cannot afford testing, and uncurious sorts who simply do not care.

This leaves a potential recoverable resource base of perhaps a few tens of millions of genomes that will be studied (in whole or in part) during the next $20-50$ years. All the valuable goods and services that medical genetics will deliver in our lifetimes must be extracted from this limited resource pool. Natural resource law frames the challenge as how to provide the best stewardship of this resource so as to maximize the extraction of useful benefits.

\section{Competition and waste}

The AMP v. Myriad decision already is enhancing competition by reducing patent barriers that blocked laboratories from offering certain kinds of test. ${ }^{11}$ There is a risk that competition may reduce the extraction of useful knowledge from the limited pool of genomes being tested. To infer the clinical meaning of particular gene variants, when the meaning is not already known, requires large population samples of genetic information that has been linked with clinical information about the tested individuals. According to a well-known principle of resource economics, when multiple operators work in a common-pool (shared) resource (CPR), they can extract more value by coordinating their efforts, and competition produces waste. ${ }^{12}$ 
In medical genetics, waste takes the form of lost or delayed opportunities to extract statistically significant new insights into the clinical validity or utility of particular gene variants. The data themselves are not wasted; properly stored data last forever. Rather, discovery opportunities are wasted when data resources grow fragmented.

Individual genetic findings are, in effect, nonrenewable resources because a person who has a gene "extracted" by one laboratory is unlikely to have that same gene tested again. A competitive testing industry divides a fixed pool of tested human genomes. Genetic data are health information, subject to privacy and human-subject protection laws that perpetuate fragmentation once it exists. ${ }^{13}$ Under the Health Insurance Portability and Accountability Act (HIPAA) Privacy Rule, ${ }^{14}$ for example, sharing data generally requires patient authorization, although HIPAA flips to a so-called liability-rule regime that overrides the need for patient permission in various circumstances. HIPAA's liability rules, for example, allow unconsented access for public health activities, for research pursuant to a waiver approved by an institutional review board or privacy board, or if data are deidentified. ${ }^{6}$

HIPAA grants individuals a degree of control over their data that is strikingly similar to what they would enjoy if they actually owned their data: property rights also sometimes flip to liability-rule protection, as when buildings are condemned for public safety or to build a highway. ${ }^{6}$ Only a few states recognize patient property rights in data, but HIPAA constrains data sharing in a surprisingly similar way. ${ }^{6}$

Once fragmentation occurs, laws such as HIPAA make it hard to reassemble the comprehensive data resources needed to discover new genotype-phenotype relationships. A widespread misconception is that data can be deidentified to comply with HIPAA and then assembled into useful data commons for such research. Deidentified data, although useful for some purposes, have very limited value if the goal is to study the clinical validity and utility of gene variants. ${ }^{6}$ Such studies require data resources that link individuals' genetic results with their clinical information. This linkage requires at least some identifying information, to verify that genetic and clinical records relate to the same individual. Supplying data in deidentified form precludes the necessary linkage. ${ }^{6}$

Data commons must be assembled through other legal pathways, such as obtaining individual authorization/consent, or investing labor and building information infrastructure to reconnect data in ways that satisfy one of HIPAA's other liability rules. Distributed data networks such as the US Food and Drug Administration's 100-million-person Mini-Sentinel system exemplify this latter approach. ${ }^{15}$ Data stay within each data holder's privacy firewall, but data holders cooperate to convert their data into interoperable formats and respond to external queries in a privacy-compliant manner. ${ }^{15}$ In theory, data are nonrivalrous and can be infinitely shared without being used up. But lawfully shared data are partly rivalrous (subject to supply constraints) because there is a finite supply of the required labor and infrastructure. ${ }^{6}$
Gene patents, whatever their flaws, had the beneficial effect of consolidating commercial exploitation of specific genes under the management of patent monopoly holders. Myriad reports a $3 \%$ rate of $B R C A$ variants of unknown significance, whereas European $B R C A$ testing services report a $20 \%$ rate of variants of unknown significance. ${ }^{8}$ Although not independently verifiable, Myriad's figure seems consistent with experience in other extractive industries, where exclusive operators tend to be effective managers of CPRs. ${ }^{12,16}$ In a total resource pool of 1 million patients undergoing $B R C A$ testing, a unitized effort that tests all million patients is more likely to extract statistically significant findings about rare gene variants than are five laboratories each doing 200,000 tests.

Resource lawyers point to the disastrous example of the East Texas Oil Field, which, when discovered, was the largest oil reservoir in the world. Because of its size, many operators leased acreage above it and competed to produce oil from the CPR. ${ }^{17}$ By 1931, their uncoordinated efforts were leaving $80-90 \%$ of the oil permanently trapped in the rocks below. ${ }^{18}$ They invested $\$ 200$ million (about a billion in today's dollars) in duplicative oil wells. ${ }^{19}$ The Texas governor sent in troops to impose production quotas that reduced the waste, but, even then, much of the recoverable oil was forever lost. ${ }^{17}$

The better solution, which most producing states embrace, ${ }^{19}$ is compulsory unitization of CPRs. ${ }^{16}$ Unitization appoints an exclusive operator to manage the $\mathrm{CPR}$ on behalf of all competing producers, who divide the proceeds using a preset formula. This eliminates waste by managing CPRs in a globally optimal manner. Compulsory unitization proved politically infeasible in East Texas amid disputes over the profit-sharing formula. ${ }^{17,19}$ Unitization tends to be more acceptable ex ante (before production begins) when competitors are behind a veil of ignorance about how rich their own portion of the resource may prove to be. ${ }^{17}$

After AMP v. Myriad, proprietary databases may become even more fragmented than they are today. Even if laboratories in aggregate test many patients, they may not be able to connect the dots to interpret what the results mean. Research investments may suffer as private-sector laboratories expand advertising in an intense competition for market share, which is crucial to a laboratory's capacity to extract statistically significant findings that improve its future ability to interpret the tests it offers. Competition thus has the potential to impede discoveries that could improve genetic test interpretation and the clinical application of genetic test results.

These predictions are not a critique of the Supreme Court's decision. Nations often do choose technically suboptimal production of their natural resources in pursuit of other important values. ${ }^{17} \mathrm{~A}$ competitive genetic testing industry has offsetting advantages, such as lowering the cost of tests and letting patients seek confirmatory testing before important medical decisions. Moreover, patent-created monopolies are not the only (or the best) way to avoid coordination problems. Gene patenting may go down in economic history as the most wasteful failure of natural resource management since the East Texas Oil Field. 
Other approaches can reap benefits of a competitive genetic testing industry while still promoting coordinated discovery and innovation. Experience shows that "neither the state nor the market is uniformly successful" in managing CPRs. ${ }^{12}$ A portfolio of approaches often is required. Voluntary cooperation sometimes emerges; there are examples of self-organized, self-governing collectives that have managed irrigation, meadowlands, and forests over hundreds of years. ${ }^{12}$ Efforts to develop voluntary, donative genetic data commons have produced successes ${ }^{20}$ and public entities such as the National Institutes of Health have promoted data sharing and helpful policy reforms. ${ }^{21}$ Still, data access remains imperfect. ${ }^{8}$ Two alternatives are compulsory disclosure and market-oriented approaches.

\section{Command-and-control regulation}

A license to mine natural resources typically carries reciprocal civic duties. A laboratory's right to mine the genome could be conditioned on sharing information about the variants it detects while doing so. This amounts to compulsory unitization of genomic data resources. The Centers for Medicare and Medicaid Services administers regulations under the Clinical Laboratory Improvement Amendments of 1988 (CLIA) 22 and has broad rulemaking authority in this area. The agency seemingly could amend its regulations to require data sharing by laboratories that perform genetic tests. These requirements would only apply prospectively, however. Forcing laboratories to share past data raises problems under the Constitution's Takings Clause, which prevents the government from confiscating private assets without just compensation. Still, it is better to implement sound natural resource policies late than never.

When the federal government imposes new regulatory duties nowadays, it often relies on public/private partnerships rather than creating new federal bureaucracies. ${ }^{23}$ Professional bodies such as the American College of Medical Genetics and Genomics (ACMG) could help the Centers for Medicare and Medicaid Services identify needed types of data sharing to reduce waste. As a condition of CLIA certification, the Centers for Medicare and Medicaid Services could require laboratories to deposit such data into a shared database, which could be operated as a financially self-sustaining public/private partnership. If the Centers for Medicare and Medicaid Services fails to act, the states have a long history with conservation to prevent waste of natural resources, although a state-led solution loses the benefits of nationally scaled coordination and some scholars question the competence of state conservation commissions to set science policy. ${ }^{19}$

The flaw in this scheme is its impact on incentives to invest in developing new information resources. If Lab A deposits 99 clinically significant genotype-phenotype correlations in a public database, and Lab B deposits just 1, then Lab A arguably deserves $99 \%$ of the revenues Lab B earns by using the shared data resource. Unless an appropriate revenue-sharing formula is agreed, mandatory data deposit rewards free riders and chills investment in data creation.
Public funding plays a crucial role in genetics, but private investment is also needed. The scholarly and scientific communities have strong norms favoring data sharing at no cost. ${ }^{3,8}$ Such norms favor static efficiency over dynamic efficiency or, in noneconomic jargon, they kill the goose that lays the golden egg. Static efficiency focuses on how best to allocate data assets that exist today. Dynamic efficiency focuses on how to ensure abundant supplies of useful data for the future $\mathrm{e}^{24}$ and is essential to sustainable discovery.

Expropriating the fruits of private investment has worked very badly in other resource industries. The United States is the only nation that maintained private ownership of its large energy and resource infrastructures throughout the 20th century. ${ }^{25,26}$ Many nations nationalized such assets at midcentury. ${ }^{18,19}$ As the 20th century ended, however, governments worldwide were turning back to private infrastructure ownership to restore efficiencies lost by placing assets under public ownership. ${ }^{27}$

Commentators who call for Myriad to disclose its data at no charge acknowledge that Myriad invested its own capital to develop these resources. ${ }^{8}$ Some scholars call it an "asymmetry" that private laboratories use publicly financed data resources while refusing to share their privately developed data. ${ }^{8}$ This is asymmetrical only if driving our cars on public highways obligates each of us to let the public sit in our own living rooms. Public and private property are different, and sound resource management respects that fact.

\section{Market-oriented solutions}

Market-based approaches are a subclass of voluntary solutions that add price incentives to the other incentives to cooperate. Voluntary need not mean gratuitous. Economic incentives are a helpful antidote to human reluctance to volunteer. Experience with other resources suggests that market-based solutions are the best way to achieve dynamic efficiency and sustainability. Environmental laws that the United States passed in the 1970s drew heavily on ethical environmentalism, which grounds duties to protect the environment in moral and aesthetic rationales. ${ }^{28}$ Scholars now regard ethical environmentalism as "a failing paradigm" unable to ensure environmental sustainability. ${ }^{28,29}$ Modern regulations reject command-and-control tactics in favor of "such efficiency-oriented instruments as tradeable permits, corrective taxes, ... and other tools designed to replicate the conditions of a well-functioning market."28

A market for genetic data could promote sharing while incentivizing investments to develop future data resources, but there are moral concerns about commoditizing patients' health data. Congress foresaw this dilemma in 2009 when passing the Health Information Technology for Economic and Clinical Health (HITECH) Act. ${ }^{30}$ HITECH added data sales restrictions to the HIPAA Privacy Rule. Under most states' laws, laboratories do not "own" the data they hold and thus have no legal basis to sell it. ${ }^{6}$ The HITECH Act does not let HIPAA-covered laboratories sell data. ${ }^{31}$

It does, however, let laboratories charge a reasonable, costbased fee for services to prepare and transmit data ${ }^{32}$ that they 
share for research under HIPAA waivers without patient authorization. ${ }^{33}$ Sharing data consumes labor and uses database infrastructure that data holders have invested to create. ${ }^{6}$ Investors are reluctant to tie up capital in activities that produce no return.

HITECH's cost-based fee, had it been implemented properly, could have strengthened incentives to share data. HITECH does not overtly let data holders charge a price for data, but their expenses and capital invested to develop the data are costs of data preparation that presumably can be recovered through the cost-based fee. Laboratories that receive data gratuitously as a by-product of providing paid testing services seemingly have zero data-development costs to recover, but laboratories that actively invest to enhance the value of their data sets presumably could track those expenditures and recover them as datapreparation costs. Cost-based fees thus create incentives that are surprising similar to market-based prices, provided the fees let investors recover a reasonable return on their invested capital.

Over the past 125 years, the Supreme Court has pondered whether it is constitutional for the government to force the use of regulated, cost-based fees in many different infrastructure contexts..$^{34}$ To be constitutional, a cost-based fee for infrastructure services must be set high enough to let investors recoup the following: (i) variable and fixed costs of providing the services, (ii) capital they invested to develop their infrastructures, and (iii) a reasonable profit margin (rate of return on capital). ${ }^{34} \mathrm{~A}$ fee that offers no reasonable prospect that private investors can earn a return on invested capital is "confiscatory" and violates the Takings Clause. ${ }^{34-37}$ Modifications to the HIPAA Privacy Rule that went into effect on 23 September $2013^{38}$ set the cost-based fee too $\operatorname{low}^{34-37}$ by omitting this third item: a return on capital invested in data development and database infrastructure.

Making matters worse, the 2012 case of Mayo Collaborative Services v. Prometheus Laboratories prevents laboratories that discover clinically useful genotype-phenotype relationships from obtaining method patents to protect this sort of discovery. ${ }^{39}$ Many laboratories have invested heavily in data infrastructure, and much more investment is required. As things stand, laboratories seemingly have no way to earn a return on these investments, other than by hoarding data as trade secrets and using their databases to add value to their own genetic testing services. Viewed this way, the problem is not that laboratories refuse to share genetic data. The problem is a defective HIPAA Privacy Rule that inflicts financial losses on laboratories that do share.

The long-term solution is to challenge the constitutionality of HIPAA's cost-based fee. This court challenge could be brought by aggrieved database investors or by patients and researchers denied access to needed data-related services because investors are unwilling to supply them under HIPAA's inadequate fee structure. In light of precedents from other infrastructure industries, ${ }^{34-37}$ the odds of a successful constitutional challenge appear rather good.

An interim solution is to arrange virtual data access through a distributed data network, instead of using HIPAA waivers to move data across privacy firewalls into a centralized data commons. Virtual access is not as good as real access to data but beats the alternative of no access, if data holders refuse to supply data at HIPAA's cost-based fee. Researchers needing to use a laboratory's data would send a question to the laboratory, which would supply research services (rather than the raw data) to answer the question and transmit the answer. Well-crafted research contracts can help researchers control the methodology and audit the results. The US Department of Health and Human Services does not "consider sale of protected health information ... to encompass payments a covered entity may receive in the form of grants, contracts, or other arrangements to perform programs or activities, such as a research study, because any provision of protected health information to the payer is a byproduct of the service being provided."38 Data holders have incentives to supply research services because they can negotiate free-market rates instead of HIPAA's cost-based fee.

Clinical test interpretation services also appear eligible for market pricing. These could include stand-alone interpretation services that help patients assess the clinical significance of variants of unknown significance detected by tests done at competing laboratories. A little-known HIPAA fact is that using an individual's data for "treatment purposes" can include treatment of other people..$^{40}$ Treatment uses of data do not require individual authorization or a waiver, so the cost-based fee would not apply. Antitrust sanctions are available if laboratories with unique and essential database assets demand monopolistic prices.

\section{Conclusion}

Gene patents rewarded innovators but did not achieve desired levels of data sharing. Compulsory data disclosure would force sharing of existing data while potentially destroying incentives to invest in sustainable data resources for the future. Solving this problem requires a portfolio of voluntary approaches that supplements donative and publicly funded data commons with market-oriented solutions that have worked well in other natural resource industries.

\section{ACKNOWLEDGMENTS}

This research was supported by the Greenwall Foundation and the University of Houston Law Foundation, with additional funding from the National Institutes of Health through grants U01HG006507 and U01HG007307. The author is the George Butler Research Professor at the University of Houston Law Center.

\section{DISCLOSURE}

The author declares no conflict of interest.

\section{REFERENCES}

1. Association for Molecular Pathology v. Myriad Genetics, 133 S.Ct. 2107 (2013).

2. U.S. Department of Commerce, US Patent and Trademark Office. Utility Examination Guidelines. Fed Regist 2001;66:1092-1099.

3. National Research Council. Sharing publication-related data and materials: responsibility of authorship in the life sciences. National Academies Press: Washington, DC, 2003. 
4. The American Heritage Science Dictionary. Houghton Mifflin Company: Boston, MA, 2005.

5. Bastida AE. The perennial questions of ownership, mineral rights and land rights: from principles to practice. In: International Mining and Oil \& Gas Law, Development, and Investment. Rocky Mountain Mineral Law Foundation: Denver, CO, 2013 (Mining Section Paper 7A).

6. Evans BJ. Much ado about data ownership. Harvard J Law Techno/ 2011;25:69130.

7. U.S. Bureau of Ocean Energy Management. Oil and gas leasing on the Outer Continental Shelf (undated). http://www.boem.gov/uploadedFiles/BOEM/ Oil_and_Gas_Energy_Program/Leasing/5BOEMRE_Leasing101.pdf. Accessed 2 July 2013.

8. Cook-Deegan R, Conley JM, Evans JP, Vorhaus D. The next controversy in genetic testing: clinical data as trade secrets? Eur J Hum Genet 2013;21: 585-588.

9. Extractive Industries Transparency Initiative. What is the EITI? http://eiti.org/eiti. Accessed 2 July 2013.

10. World Health Organization. Health through safe drinking water and basic sanitation, 2013. http://www.who.int/water_sanitation_health/mdg1/en/. Accessed 2 July 2013.

11. Langreth R, Pettypiece $S$. Myriad gene patent ruling triggers race for cancer tests. Bloomberg, 14 June 2013. http://www.bloomberg.com/news/print/201306-14/myriad-gene-patent-ruling-triggers-race-for-cancer-tests.html. Accessed 1 July 2013.

12. Ostrom E. Governing the commons: the evolution of institutions for collective action. Cambridge University Press: New York, 1990.

13. Reichman JH, Uhlir PF. A contractually reconstructed research commons for scientific data in a highly protectionist intellectual property environment. Law Contemp Prob/ 2003;66-SPG:315-462.

14. Health Insurance Portability and Accountability Act of 1996, Pub. L. No. 104 191, 110 Stat. 1936 (codified as amended in scattered sections of 18, 26, 29 , 42 USC); see regulations at 45 CFR pts. 160, 164.

15. Platt R, Carnahan RM, Brown JS, et al. The U.S. Food and Drug Administration's Mini-Sentinel program: status and direction. Pharmacoepidemiol Drug Saf 2012;21(suppl 1):1-8.

16. Kaffine DT, Costello CJ. Unitization of spatially connected renewable resources (NBER working paper no. 16338). National Bureau of Economic Research: Cambridge, MA, 2010.

17. Roe MJ. Backlash. Columbia Law Rev 1998:98:217-241.

18. Marshall JH, Meyers NL. Legal planning of petroleum production. Yale Law J 1931:41:33-68.

19. Weaver JL. The tragedy of the commons from Spindletop to Enron. J Land Res Environ Law 2004:24:187-193.

20. Free the Data. http://www. free-the-data.org. Accessed 24 August 2013.

21. Rai AK. Patent validity across the Executive Branch: ex ante foundations for policy development. Duke Law J 2012;61:1237-1281.

22. Clinical Laboratory Improvement Amendments of 1988, Pub. L. No. 100-578, 102 Stat. 2903, codified as amended at 42 USC $\S 263$; see regulations at 42 CFR pt. 493.
23. Salamon LM. The new governance and the tools of public action: an introduction. In: Salamon LM, ed. The Tools of Government. Oxford University Press: New York, 2002.

24. Spulber DF, Yoo CS. Mandating access to telecom and the internet: the hidden side of Trinko. Columbia Law Rev 2007;107:1822-1907.

25. Gómez-Ibáñez JA. Regulating infrastructure. Harvard University Press: Cambridge, MA, 2003.

26. Chen J. The nature of the public utility: infrastructure, the market, and the law. Northwestern Univ Law Rev 2004:98:1617-1708.

27. Klingebiel $D$, Ruster J. Why infrastructure financing facilities often fall short of their objectives (World Bank policy research working paper no. 2358). World Bank Group: Washington, DC, 2000.

28. Kysar DA. Law, environment, and vision. Northwestern Univ Law Rev 2003;97:675-729.

29. Hughes H. Enabling investment in environmental sustainability. Indiana Law J 2010;85:597-651.

30. Pub. L. 111-5, Div. A, Title XIII, Div. B, Title IV, 123 Stat. 226, 467 (17 February 2009).

31. 42 USC $\$ 17935(d)(1)$

32. 42 USC $\S 17935(d)(2)$

33. 45 CFR § $164.512(i)$.

34. Phillips CF. The regulation of public utilities, 3rd edn. Public Utilities Reports: Arlington, VA, 1993

35. Chicago Milwaukee \& St. Paul Ry. Co. v. State of Minnesota ex rel. Railroad and Warehouse Commission, 134U.S. 418, 458 (1890).

36. Bluefield Water Works \& Imp. Co. v. Public Service Commission, 262 U.S. 679, 692-693 (1923)

37. Federal Power Commission v. Texaco, 417U.S. 380, 391-392 (1974)

38. U.S. Department of Health and Human Services. Office for Civil Rights. Modifications to the HIPAA Privacy, Security, Enforcement, and Breach Notification Rules Under the Health Information Technology for Economic and Clinical Health Act and the Genetic Information Nondiscrimination Act; Other Modifications to the HIPAA Rules. Fed Regist 2013;78:5566-5702.

39. Mayo Collaborative Services v. Prometheus Laboratories, 132 S.Ct. 1289 (2012).

40. U.S. Department of Health and Human Services. Office for Civil Rights. Health Information Privacy, Frequently Asked Questions. http://www.hhs.gov/ocr/ privacy/hipaa/faq/right_to_request_a_restriction/512.html. Accessed 22 August 2013. 